\title{
THE FARM FORESTRY SITUATION IN BRITISH COLUMBIA
}

\section{By W. G. HUGHES ${ }^{1}$}

Although some farmers in some parts of British Columbia have made important contributions to our timber requirements, their cutting practices have usually not been influenced by any thought of continuous production. Their chief concern has been the need for cleared land and any, supplemental revenue obtained from the sale of forest products has been considered incidental to this objective.

The practice of farm forestry in the Province has been slow to develop for a number of reasons. The limited area of farmland $(4,000,000$ acres according to the 1941 census) representing less than two per cent of the area of the Province indicates that farm forestry will never play a major part in supplying our timber needs. It is only during the last few years that diminishing supplies of timber and a rapidly increasing population have created any demand for material available from farm woodlots. Forest industry, with only minor exceptions, has not yet reached the point where it is seriously interested in farmer wood. However, with the establishment of new and diversified wood-using industries and improved techniques for handling and processing wood, developed since the last war, the market outlook for farm forest products appears encouraging. The resulting use of an increasing proportion of small wood is especially favourable since most woodlots have an over-abundance of this material. The increasing demand for low grade logs and the higher price paid for forest products in general have strengthened the demand for second growth stands in the farm woodlot.

The availability of market outlets for woodlot material in itself is not enough. It is important that these easily accessible forests be managed for continuous production. To realize this objective will call for an intensive program of education and technical assistance. Some stimulus is required to obtain the co-operative interest of the farmer. It was with this thought in mind that the "Forest Act of British Columbia" was amended in 1948 to provide for the granting of "Farm Woodlot Licences."

This is not the first time that the Forest Service has encouraged forest enterprise on the part of the farmer. In the East Kootenay region of the Province are extensive areas supporting young stands of low-site Douglas fir ideally suited to the production of valuable Christmas tree crops. In 1941 the first permits were issued to farmers to crop these stands on a sustained yield basis. Permits are now issued over specific areas for five year periods and permittees are assured of continuous use of the area assigned to them so long as they adhere to the contract conditions. Permits usually provide for an annual cut of 2,500 trees each and call for specified standards of slash disposal and stand improvement. The cut is purposely kept low to encourage good silvicultural practices, the reward being increased cut made possible by good practice. Over 100 permits are in good standing and the revenue provided by the sale of this minor forest product is an important part of this region's economy.

The farm woodlot licence is designed to be more general in applica-

1. British Columbia Forest Service, Victoria, B.C. 
tion. Any bona-fide farmer may apply for such a licence whether or not he owns forest land. However, a licence cannot be granted when suitable Crown forest land is not available within a reasonable distance of the farm.

A farm woodlot licence is limited in size to a maximum of 640 acres or an area of forest land which will produce annually not more than 10,000 cubic feet of wood products, whichever is the lesser. Usually the maximum acreage in coastal regions will range between 100 and 150 acres, whereas in the interior of the Province it might be 250 or more.

Where an applicant owns forest land he must combine this with the Crown land area, the whole to be managed as a unit. If his own land is capable of the maximum yield allowed under this plan he is, of course, not eligible for a parcel of Crown land. Forest land included in this plan must be within a reasonable distance of the farm and although no set distance is specified it must be such that the woodland can be economically maintained in conjunction with the farm.

The Crown land portion of the licence is free from ground rental, forest protection tax, or other dues, fees or taxes. Stumpage, inclusive of royalty, is payable as appraised by the Forest Service, on all material removed from the Crown land portion of the licence.

Providing the terms of the contract are being carried out the licencee is eligible to secure other Crown timber through the usual channels. As an expression of good faith a deposit of $\$ 250.00$ is required; Fifty dollars is to be paid when the licence is granted and the balance to be made up by paying so much per unit of wood removed. This supplementary deposit is in addition to stumpage and royalty.

When a licencee sells or otherwise disposes of his farm the Crown land portion reverts to the Crown, but should the new owner express a desire to maintain the licence, it may be reassigned to him.

In return for an assured supply of wood products a licencee is expected to satisfy the following three basic conditions:

1. The lands are to be kept stocked with forest growtli saleable commercial species.

2. They are to be managed by the licencee for the perpetual yield of an annual or periodic harvest of wood.

3. The established yield is to be harvested annually or periodically.

Prior to the granting of a woodlot licence a management plan for the unit must be submitted. Although the applicant is not required to draw up the management plan, he is expected to accompany the forest officer making the field examination of the licence area. In this way he gains a general understanding of the principles and objectives of the plan. The farmer and the forester both benefit from this joint approach to the problem. No charge is made by the Forest Service for preparing the management plan. The "Forest Act" states that this plan may be prepared by the farmer, his agent or the forest service. Since few applicants are expected to be sufficiently familiar with forest principles to prepare their own the Forest Service has undertaken to fulfill this requirement for the present. 
phasize the productive capabilities and the monetary values obtainable from well managed woodlands. By proper development these areas can serve as "show windows" for the cause of forestry.

Although there are limitations to the success of farm forestry in British Columbia there is much than can and should be done. Initial work in this field, though limited, has served to show that a little promotion can produce a lot of interest. Forest industry and the Government both have a part to play in supplying the necessary incentive for an improved farm woodlot situation in British Columbia. 